\title{
Comparative study between free and immobilized Penicillium chrysogenum mannanase: a local fungal isolate
}

\author{
Al Shimaa Gamal Shalaby", Mona Abdeltawab Esawy, Magdel-Din M. Hussein \\ Department of Chemistry of Natural and Microbial Products, National Research Center, Dokki, Cairo, Egypt.
}

\section{ARTICLE INFO}

Article history:

Received on: 26/01/2017

Accepted on: 10/04/2017

Available online: 30/06/2017

\section{Key words:}

Penicillium chrysogenum,

Mannanase, Immobilization,

Mannooligosaccharides,

Prebiotic activity.

\begin{abstract}
A search for fungal isolate with higher mannanase activity indicated that the local isolate Penicillium chrysogenum appeared as the most active one. Penicillium chrysogenum mannanase was eluted as one band near $30 \mathrm{~kb}$ by means SDS-PAGE at one step purification. Immobilization of the mannanase by entrapping this enzyme preparation in calcium alginate beads was carried out. The optimum temperature for both free and immobilized mannanase form unchanged $\left(50{ }^{\circ} \mathrm{C}\right)$. The optimum $\mathrm{pH}$ of the free enzyme was 6 while the immobilized form achieved it at $\mathrm{pHs}$ range 6-6.5. At $70^{\circ} \mathrm{C}$ the immobilized form could retain $41 \%$ of its activity after $180 \mathrm{~min}$, while the free enzyme lost $88 \%$ of its original activity at the same time. The immobilization reduced the activating energy from $21.36 \mathrm{kcal} \mathrm{mol}^{-1}$ to $17.79 \mathrm{kcal} \mathrm{mol}^{-1}$. Also, it was prolonged the half-lives and D values remarkably in compared to the free enzyme. Shelf stability study indicated that the immobilized form was stable at $4{ }^{\circ} \mathrm{C}$ retaining $90 \%$ of the activity after 60 days. Bioconversion of locust bean gum (LBG) and yeast mannan by partially purified mannanase (PPM) was similar (41\%) for free PPM and 23\% for the immobilized form. The prebiotic activity of mannooligosaccharides (MOS) are comprising bio-converted samples of LBG and yeast mannan towards the probiotics Lactobacillus casei, Lactobacillus helveticus and Lactobacillus reuteri. Noteworthy is the highest prebiotic activity (prebiotic index 247) was recorded for MOS (of LBG) towards L. helveticus.
\end{abstract}

\section{INTRODUCTION}

Polysaccharides, like mannans, are found as linear homopolysaccharides, heteropolysaccharides or branched form. Mannans are one of the major components of hemicelluloses and in the yeast cell wall. Mannanases are enzymes which have a great impact in the application of industrial processes such as biobleaching of pulp, detergent industry, food and pharmaceutical productions e.g. mannooligosaccharides (MOS) (Mc Cleary et al., 1988), also in various other industries. The composition of mannan is mainly influenced by the action of more than one enzyme. So that degradation of heteromannan, like locust bean gum, can be achieved by fungi and bacteria using different microbial enzymes. Furthermore, MOS prepared

\footnotetext{
* Corresponding Author

Email: shimaagamalnrc@gmail.com
}

by enzyme degradations are used as prebiotics namely as, a nondigestible food ingredient that have been affected the host by selective stimulation of the growth and/or activity of one or a limited number of bacteria in the colon, and thus improves host health (Lee and Salminen, 2009).

It is generally known that microorganisms are the best source of enzymes. There are three kinds of mannanases which produced by filamentous fungi such as Penicillium strains. A restriction is that the organisms, employed to produce a product, should be a virulent and the resulting product, is non-toxic (Whistler and BeMiller, 1993). Actually, these restrictions become more eased by immobilization of enzymes. This technique is characterized by many advantages including stability and reusability of the immobilized enzyme. Enhancement of activities of immobilized enzymes was achieved using various processes, which are classified as chemical, somewhere the enzyme consists covalent and physical bonds, where the enzyme weakly interacted with support. 
According to Blibech et al., (2011), locust bean gum (LBG) was mainly hydrolyzed into MOS i.e., mannotriose and mannotetraose. LBG is a galactomannan while yeast polysaccharide is a mannan. As a trail, the resulting MOS were examined for their benefit effect for growing of lactobacteria as a specific nutrient. The aim of this study is investigating the immobilization of mannanase and to evaluate its biological activity as prebiotic agent for hydrolysate MOS productions (Tomotari and Indus 1990; Titapoka et al., 2008; Quigley, 2010; Gibson et al., 2004; Yopi et al., 2006; Ariandi et al., 2015) and efficiency of hydrolysis.

Currently, consumer is more aware of using of food that decreases the potential risk of diseases and enhancement of wellbeing better health. In this view, there is plenty of interest of nondigestible oligosaccharides as specific kinds of dietary carbohydrates regarded as prebiotics. For many years, modern societies have been consumed various products that promoting the level of health in the general population considered as prebiotic and probiotic properties and advocated for their benefits on health and gastrointestinal well-being. Recently, medical science has been a lot of attention paid in the population of micro-organisms, the intestinal gut microbiota which inhabit the human gut, and the scope of the tasks to be undertaken in the area of health. As a result, the list of disorders and diseases that will result from disruption of the normal microbiota and/or its interaction with the host is growing. A scientific reason for the utilization of probiotics and prebiotics is, therefore, beginning to widespread.

\section{MATERIALS AND METHODS}

\section{Materials}

Fungal isolate

Penicillium chrysogenum was donated by Prof. Dr. A.F. Sehab, Department of plant protection, NRC. It was isolated from old deteriorated valuable manuscript (A) sultan, Malak, library No.1405 present in the stores of general Egyptian Book organization (G.E.B.O), Cairo Governorate, Egypt.

\section{Bacterial Strains}

Three bacterial strains were used for the study and investigation of the prebiotic activity. These included L. casei, $L$. helveticus and $L$. reuteri which are Gram-positive bacteria. They were provided by Chr. Hansen's Lab. Inc., Denmark. Pathogenic strain, Escherichia coli (Gram-negative), was obtained from the clinical lab of the El Demerdash Hospital in Cairo Governorate.

\section{Culture Media}

Potato Dextrose Agar (PDA): was used to maintain the fungal isolate, Modified Liquid Mandels medium was used for the growth of Penicillum strain which cultivated for mannanase production (Chaabouni et al., 1995), De Man- Rogosa- Sharpmedium (MRS medium): was used for growing and maintenance of the probiotics, L. casie, L. reuteri and L. helveticus, M.R.S. broth medium was used to determined the growth intensity of the investigated probiotics by substitutable of carbon source by the produced MOS. The prepared MRS broth tubes were inoculated, then incubated anaerobically at $37^{\circ} \mathrm{C}$ for 24 hours and sub-cultured every month.

\section{Methods}

Screening of fungal isolates (microorganism) for their ability to produce mannanase

Many fungal isolates belonging to the genera Penicillium, Trichoderma and Aspergillus were examined for mannanase activity. So, the studied fungal isolates were grown on a modified medium known as Liquid Mandels. This medium comprised $2 \% \mathrm{KH}_{2} \mathrm{PO}_{4} ; 5 \% \mathrm{NaNO}_{3} ; 0.3 \% \mathrm{MgSO}_{4} 7 \mathrm{H}_{2} \mathrm{O} ; 0.3 \%$ $\mathrm{CaCl}_{2} ; 1 \%$ yeast extract; $10 \%$ guar gum, $1 \%$ tween 80 . The same medium was also used for the preparation of crude mannanase.

\section{Production of crude mannanase by $P$. chrysogenum}

The fungal isolate $P$. chrysogenum was cultivated in the modified "Mandels" medium after sterilization medium at $121^{\circ} \mathrm{C}$ for $30 \mathrm{~min}$, cooled and inoculated with $2 \%$ inoculum. The production of crude mannanase was done under aerobic conditions (shaking at $180 \mathrm{rpm}$ ) using guar gum as $\mathrm{C}$ source, at $30^{\circ} \mathrm{C}$ and $\mathrm{pH}$ 5.5 for $120 \mathrm{hr}$. The culture filtrate $(\mathrm{CF})$ was used as the crude enzyme for assay.

\section{Determination of mannanase activity and protein}

Mannanase product $(0.5 \mathrm{~mL})$ was added to $0.5 \mathrm{~mL} \mathrm{LBG}$ $(0.5 \% \mathrm{w} / \mathrm{v})$ dissolved in $50 \mathrm{~m} \mathrm{M}$ sodium acetate buffer $(\mathrm{pH} 5.5)$. The reaction mixture was incubated at $50^{\circ} \mathrm{C}$ for $30 \mathrm{~min}$. Reduced sugars released from LBG were quantified by the method reported by Neish (1952) and based on those described by Somogi (1952). The assay was expressed as one unit of mannanase activity produce $1 \mu \mathrm{mol}$ of mannose per min. Protein concentration was determined as described by Lowry et al. (1951).

\section{Fractional precipitation with acetone}

Acetone was used by different concentrations (20-40-

60-80\%). It was added gradually to the ice-cold enzyme solution until reach the demanded concentration. The resulted supernatant were centrifuged at $4000 \mathrm{rpm}$ for $10 \mathrm{~min}$ to remove the precipitated fraction, the process was repeated until the final acetone concentration was reached (80\%). Different acetone fractions were dried over anhydrous calcium chloride, under reduced pressure at room temperature, weighed and their activity and protein were calculated.

\section{Disc-electrophoresis for the purified mannanase}

Polyacrylamide gel disc electrophoresis was carried out according to Laemmli (1970).

\section{Enzyme immobilization by cross linking in calcium alginate beads}

Two $\mathrm{mL}$ sodium alginate $(4 \%)$ and $0.5 \mathrm{~mL}$ of the PPM $(0.02 \mathrm{gm})$ in the ratio $(2: 0.5)$ were dissolved in $0.1 \mathrm{M}$ acetate 
buffer and the resulted viscous mixture was dropped (with suitable dropper) into cold $20 \mathrm{~mL}$ calcium chloride solution $(0.2 \mathrm{M})$. The formed calcium alginate beads (comprising the encapsulated mannanase) were stored in a refrigerator for $24 \mathrm{hr}$., and then the unbounded enzyme was removed by washing with distilled water

Immobilization yield was defined as follow

Yield $\%=($ Total enzyme activity - unbound enzyme activity / Total enzyme activity) x 100

\section{Effect of different parameters on free and immobilized form}

In this experiment, equal reaction mixture of the free and immobilized enzyme was incubated at different temperature (40$70^{\circ} \mathrm{C}$ ) for $30 \mathrm{~min}$ and $\mathrm{pH} 5.5$. Effect of $\mathrm{pHs}$ was done at the same procedure from $\mathrm{pH}(3,3.5,6,6.5)$ and enzyme assay was achieved at the optimum conditions. Reaction time was also done at different time intervals $(30-120 \mathrm{~min})$ and same previous procedures.

Free and immobilized mannanase was expressed as activation energy $\left(E_{a}\right)$ and determined from the slope of the Arrhenius plot [log V (logarithm of \% residual activity) versus reciprocal of absolute temperature in Kelvin (1000/T)], which is given by the following Eq. (2)

$$
\text { Slope }=-\frac{E_{a}}{R}
$$

Where $R$ is the gas constant $\left(8.314 \mathrm{~mol}^{-1} \mathrm{k}^{-1}\right)$

\section{Thermal stability}

The free and immobilized enzyme forms were preincubated at various temperatures in between 50 to $80{ }^{\circ} \mathrm{C}$ up to 3 h. Each sample was withdrawn after $30 \mathrm{~min}$ and its activity was determined at the optimized conditions. The residual activity was determined by considered the activity of enzyme at 0 minute as $100 \%$. Previous results were also expressed as first order thermal deactivation rate constants $(\mathrm{kd})\left(60-80^{\circ} \mathrm{C}\right)$. The $\mathrm{t} 1 / 2$ (half-lives) and D values for both was calculated from the equation 1, 2 . Results were also expressed as first order thermal deactivation rate constants $(k \mathrm{~d})\left(60-80^{\circ} \mathrm{C}\right)$. The $\mathrm{t} 1 / 2$ (half-lives) and $\mathrm{D}$ values for free and immobilized amylase was evaluated according to the equation 1,2 .

$$
\begin{gathered}
t 1 / 2=\ln 2 / k d(1) \\
\text { D-value }=\ln 10(2) \mathrm{kd}
\end{gathered}
$$

The temperature rise necessary for reduction $D$-value by one logarithmic cycle ( $\mathrm{z}$ value) was calculated from the slope of graph, $\log \mathrm{D}$ versus $\mathrm{T}\left({ }^{\circ} \mathrm{C}\right)$ using the equation:

$$
\text { Slope }=\frac{-1}{\mathrm{z}}
$$

The activation energy (Ed) for mannanse denaturation was calculated by plotting log denaturation rate constants (lnkd) versus reciprocal of the absolute temperature $(\mathrm{K})$ according to the Eq (2).

$$
\text { Slope }=-E d / R(2)
$$

\section{Bioconversion of locust bean gum (LBG) and yeast mannan by the free and immobilized form}

Bioconversion process was achieved applying a suitable enzyme: substrate (E/S) ratio: $37 \mathrm{U} / 2.5 \mathrm{mg}$ substrate for free and immobilized PPM. Bioconversion conditions included the previously concluded optimal temp. $\left(50^{\circ} \mathrm{C}\right)$ and $\mathrm{pH}$ value $(\mathrm{pH} 6)$ after $90 \mathrm{~min}$ (in case of free form) or $120 \mathrm{~min}$ (in case of immobilized form).

\section{Quantitative paper chromatography $(P C)$ of hydrolyzed mannan}

Hydrolysed mannan was separated by Chromatographic technique which carried out on Whatman chromatographic filter paper (No. 1) using the solvent: n-butanol - acetone - water in the ratio 4:5:1 v/v (Jayme and Knolle, 1956 and Percival, 1968). Quantitative determination of the separated sugars was done according to the method adopted by Wilson, (1959) as follows:-

\section{Color reagent}

O-phthalic acid (1.66 g) and $0.91 \mathrm{~mL}$ aniline were dissolved in a mixture of n-butanol, diethyl ether and water by ratio: $48: 48: 4$.

\section{Eluting agent}

This consisted of $0.7 \mathrm{~N} \mathrm{HCl}$ in $80 \%$ ethanol (v/v). The mixture consisted of $29 \mathrm{~mL}$ of $36 \% \mathrm{HCl}$ to $420 \mathrm{~mL}$ of $95 \%$ ethanol and it was made up to $500 \mathrm{~mL}$ with distilled water.

\section{Procedure}

After the separation by chromatography, the air dried chromatograms were sprayed $(40-50 \mathrm{~mL})$ of the color reagent. The developing colors of spots were observed after the chromatograms were air dried and then heated in an oven at $105^{\circ} \mathrm{C}$ for $10 \mathrm{~min}$. The spots were divided into small strips and dropped into test tubes. Elution process occurred by adding $4 \mathrm{~mL}$ of eluting agent to each tube and shaken. The resulting solutions were determined by absorbance measurement in a BAUSCH and LOMB spectronic 2000 spectrophotometer at $390 \mathrm{~nm}$ for hexoses, and at $360 \mathrm{~nm}$ for pentoses. The sugars quantities were estimated by comparison to appropriate standard curves.

\section{Prebiotic activity}

Prebiotic activities of two samples of the enzymatically prepared mannooligosaccharides were evaluated. Experimentally, the three probiotics L. Casei, L. reuteri and L. helveticus were grown on the MRS medium, while $E$. coli was grown in nutrient broth medium, at $37^{\circ} \mathrm{C}$ for $24 \mathrm{~h}$. Aliquots of $0.1 \mathrm{~mL}$ of each of the resulted bacterial culture were used as inoculum for $10 \mathrm{~mL}$ studied medium supplemented with $150 \mathrm{mg}$ studied MOS samples as carbon source. After incubation at $37^{\circ} \mathrm{C}$ for $24 \mathrm{~h}$, the resulted 
bacterial growth was measured at $625 \mathrm{~nm}$ against a blank of un inoculated medium Hussein et al., (2015). The prebiotic activity was calculated as "Prebiotic Index" (I):

Prebiotic index $=($ Optical density of probiotic culture at $600 \mathrm{~nm} /$ Optical density of $E$. coli culture at $600 \mathrm{~nm})$ x 10

\section{Storage stability}

Both the immobilized and free PPM was stored in distilled water at $4{ }^{\circ} \mathrm{C}$ for 2 months. The activity was measured every 2 weeks using $5 \mathrm{mg}$ of protein.

\section{RESULTS AND DISCUSSION}

\section{Searching for fungal isolate with higher mannanase activity}

A Search for fungal strain characterized by its relatively higher mannanase activity was done. The search included many isolates belonging to the genera Penicillium, Trichoderma and Aspergillus. Qualitative examination (appears of reducing groups) of the hydrolytic action of these fungi (grown on guar), revealed that all isolates were negative except $P$. chrysogenum exhibited the promising mannanase activity $(80 \mathrm{U} / \mathrm{mL})$. In agreement with this observation, mannanas enzymes were found to be secreted by different microbes including fungi, yeasts and bacteria (Dhawan and Kaur, 2007; Blibech, et al., 2011; Dan et al., 2012). The fungal strain was considered as mannanase producer. It produces three types of mannanase, one of them (mann III) can produce mannooligosaccharides (MOS) from LBG and ivory nut mannan (Blibech et al., 2010). So, $P$. chrysogenum was used, in the next part of this work, for the preparation of considerable amount of crude and partially purified mannose products.

\section{Production of crude mannanase by $\boldsymbol{P}$. chrysogenum}

The fungal isolate $P$. chrysogenum was grown on the modified "Mandels" medium under aerobic conditions (shaking at $180 \mathrm{rpm}$ ) using guar gum as $\mathrm{C}$ source, at $30^{\circ} \mathrm{C}$ and $\mathrm{pH} 5.5$ for 120 hr. Similarly, it was reported in the production of $P$. occitanis mannanase using locust bean gum (Blibech et al., 2011). After centrifugation, the resulted culture filtrate was analyzed for its mannanase activity and protein content. Specific mannanase activity of the crude product (CF) as found: $24 \mathrm{U} / \mathrm{mg}$ protein. Blibech et al. (2011) reported in partial purified mannooligosaccharides where the specific activity was $12 \mathrm{U} / \mathrm{mg}$.

\section{Preparation of a partially purified mannanase, produced by $\boldsymbol{P}$. chrysogenum}

Enzyme fractionation by acetone reported that all started mannanase activity was precipitated at $60 \%$ acetone (40000 U) and $1075 \mathrm{mg}$ protein, while completely absent at $20 \%, 40 \%$ and $80 \%$. Traces of protein were obtained at $20 \%$ and $40 \%$ acetone. SDS-PAGE results indicated that the enzyme was eluted in single band near $30 \mathrm{~kb}$ (Figure 1). Specific mannanase activity (of the prepared partially purified product) was found: $37 \mathrm{U} / \mathrm{mg}$. These data indicated that the yield of the partially purified mannanase was $90 \%$ and 1.54 purification fold. In a similar study (Blibech et al., 2011) the CF (crude enzyme) of $P$. occitanis was treated with $60 \%\left(\mathrm{NH}_{4}\right)_{2} \mathrm{SO}_{4}$, the partially purified mannanase ( precipitated) exhibited specific activity of $12 \mathrm{U} / \mathrm{mg}$ protein with a yield of $99.4 \%$ and 2.33 purification fold.

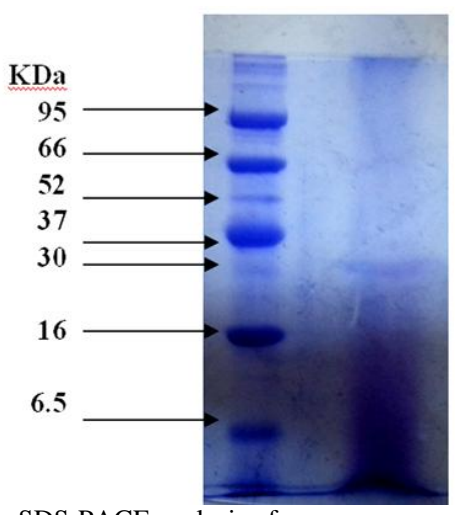

Fig. 1: SDS-PAGE analysis of mannanase enzyme.

\section{Characterization of the partially purified mannanase product}

This included studies on the effects of temperature, $\mathrm{pH}$ values and reaction period on the enzyme activities of the partially purified mannanase product.

\section{Immobilization of the partially purified mannanase}

This was achieved by entrapping the partially purified enzyme, in calcium alginate beads. Approximately, the whole of enzyme was entrapped reported $100 \%$ immobilization yield.

\section{Effect of temperature for free and immobilized PPM}

The present investigation aimed to evaluate the effect of different temperature on free and immobilized form. Amongst the studied temperature $\left(40,45,50,55,60,65\right.$ and $\left.70^{\circ} \mathrm{C}\right)$, the degree $50{ }^{\circ} \mathrm{C}$ was recorded as the optimal temp for both free and immobilized form (Figure 2a).

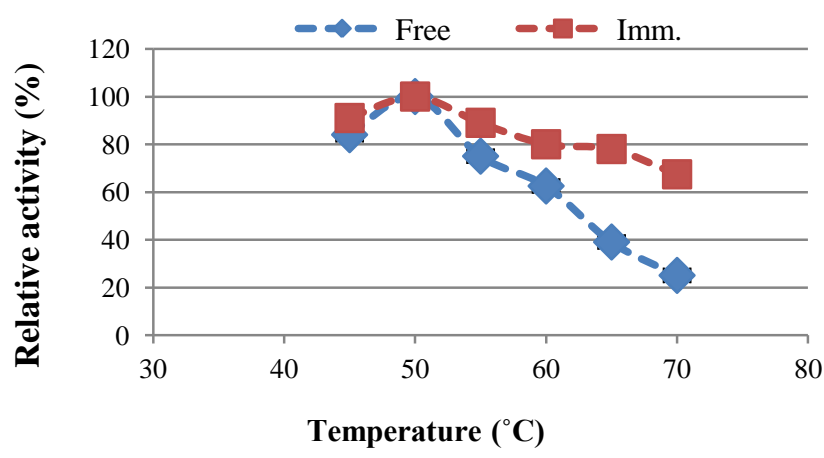

Fig. 2a: Effect of temp. on activity of free and immobilized PPM.

Also, the results indicated clearly to the effect of immobilization process in protect the enzyme activity to great extent in compared to the free form while, the free enzyme lost $75 \%$ of its original activity at $70^{\circ} \mathrm{C}$ and the immobilized form kept $76.4 \%$ of its activity at the same degree. On contrary, 
Paenibacillus sp. DZ23 and B.subtilis NM-39 showed the optimum productivity of mannanase at $37^{\circ} \mathrm{C}$ (Chandra et al., 2011; Mendoza et al., 1994).

Also, the optimal temp. recorded for the mannanase produced by immobilized and free $P$. occitanis were $70^{\circ} \mathrm{C}$ (Blibech et al., 2011). This indicated that the P. chrysogenum mannanase is more susceptible to temp. higher than $50^{\circ} \mathrm{C}$, as compared to that of $P$. occitanis (Blibech et al., 2011). Accordingly, the result pointed to the role of immobilization process in PPM protection.

\section{Activation energy of free and immobilized mannanase $\left(E_{a}\right)$}

The immobilization process reduced the activating energy from 21.40 to $17.80 \mathrm{kcal} \mathrm{mol}-1$ (Figure $2 \mathrm{~b}$ ). This means that the immobilization process save energy and consequently the immobilized form was economically most favorable. Similar observation was reported by Esawy et al. (2013) where the immobilization process reduced the activation energy from 5.1 to $2.7 \mathrm{kcal} \mathrm{mol}^{-1}$.

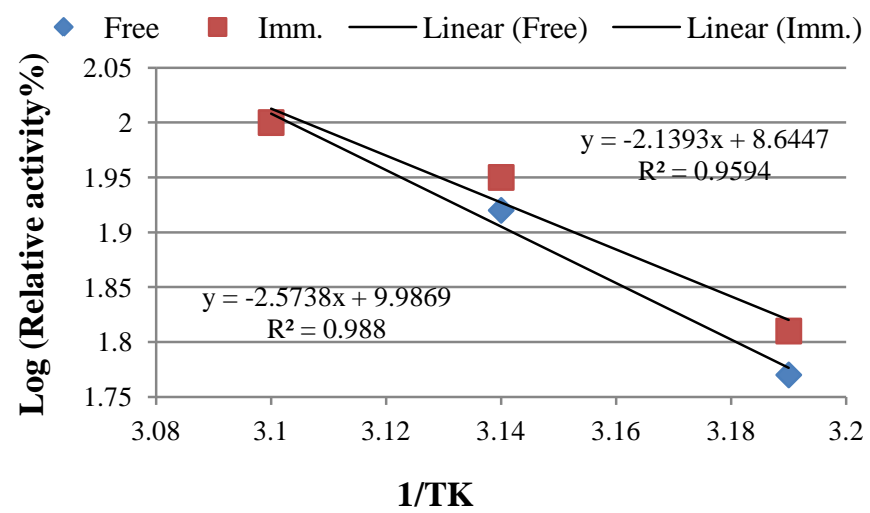

Fig. 2b: Arrhenius plot to calculate the activation energy of mannanase $\left(E_{a}\right)$.

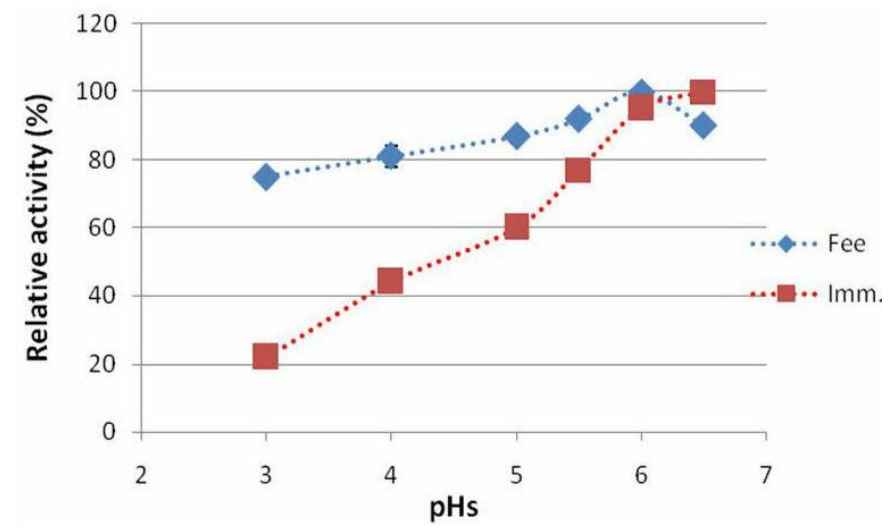

Fig. 3: Effect of pH-value on the activity of free and immobilized mannanase.

\section{Effect of pH-value for the free and immobilized PPM}

The goal of this experiment was to identify the optimal $\mathrm{pH}$-value required for exhibition of the highest enzyme activity for the free and immobilized PPM at fixed temp. $\left(50^{\circ} \mathrm{C}\right)$ and reaction time $(30 \mathrm{~min}$ ). The optimum $\mathrm{pH}$ was determined to be 6 and 6.5 for free and immobilized form respectively (Figure 3 ).

\section{Effect of reaction time in free and immobilized mannanase}

The aim of this investigation was to define the longest reaction time at which, mannanase activity still appeared at its higher value. This was carried out at the optimum conditions for both free and immobilized form. The results indicated that the optimum time for the highest PPM was 90 and $120 \mathrm{~min}$. for free and immobilized form respectively. This result could be explained that the immobilization process prolonged the diffusion time to contact with the substrate. In a similar work on P. occitanis mannanase (Blibech et al., 2011), the longest reaction time at which the enzyme activity was still higher was found to be $30 \mathrm{~min}$ at $70{ }^{\circ} \mathrm{C}$ and $\mathrm{pH} 4$.

This refers to $P$. chrysogenum mannanase as a more stable enzyme preparation (at its own optimal temp. and $\mathrm{pH}$ value) comparing to that of $P$. occitanis.

\section{Thermal stability}

Thermal study was done to evaluate the role of immobilization process in enzyme thermal stability improvement. The results (Figure $4 \mathrm{a}, \mathrm{b}$ ) indicated that the immobilization process improved the enzyme stability remarkably. At $70{ }^{\circ} \mathrm{C}$ the immobilized form could retained $41 \%$ of its activity after $180 \mathrm{~min}$, while the free enzyme lost $88 \%$ of its original activity at the same time, while at $80{ }^{\circ} \mathrm{C}$ the immobilized form retained $30 \%$ of its activity in compared to $10 \%$ for free form after the same time. The immobilized $\beta$ - mannanase showed more stability than the free enzyme, particularly if the temperature exceeded $50{ }^{\circ} \mathrm{C}$. The heat inactivation rate was studied for both enzyme forms. Log $(\%$ remaining activity) plots vs. time were linear indicating the first order kinetics of immobilized enzyme (Figure 4c, d). The Ed of the immobilized form reported $26 \mathrm{~kJ} \mathrm{~mol}^{-1}$ in compared to $23 \mathrm{~kJ}$ $\mathrm{mol}^{-1}$ free enzyme (Figure 4e, f).

This means that more energy was required to denature the immobilized form (Driss et al., 2014). Also, the halves lives and D values were prolonged clearly after the immobilization. Since the half lives for the immobilized form reported 383, 313 and $222 \mathrm{~h}$ at 60,70 and $80{ }^{\circ} \mathrm{C}$ in compared to 202, 156 and $130 \mathrm{~h}$ for PPM at the same temperature. Also, D values reported 676, 522, 460 ( $\mathrm{min})$ and 1277, 1045, 741 (min) for free and immobilized PPM. The $\mathrm{z}$ value for the free and immobilized form was calculated to be $85,119{ }^{\circ} \mathrm{C}$ respectively (Figure $4 \mathrm{~g}$ ).

The high magnitude of $\mathrm{z}$ values pointed to more sensitivity to the duration of heat treatment and the low $\mathrm{z}$ value meant more sensitivity to the increase in temperature (TayefiNasrabadi and Asadpour, 2008). All previous results suggested that the immobilization process acquired the PPM rigidity and stability. 

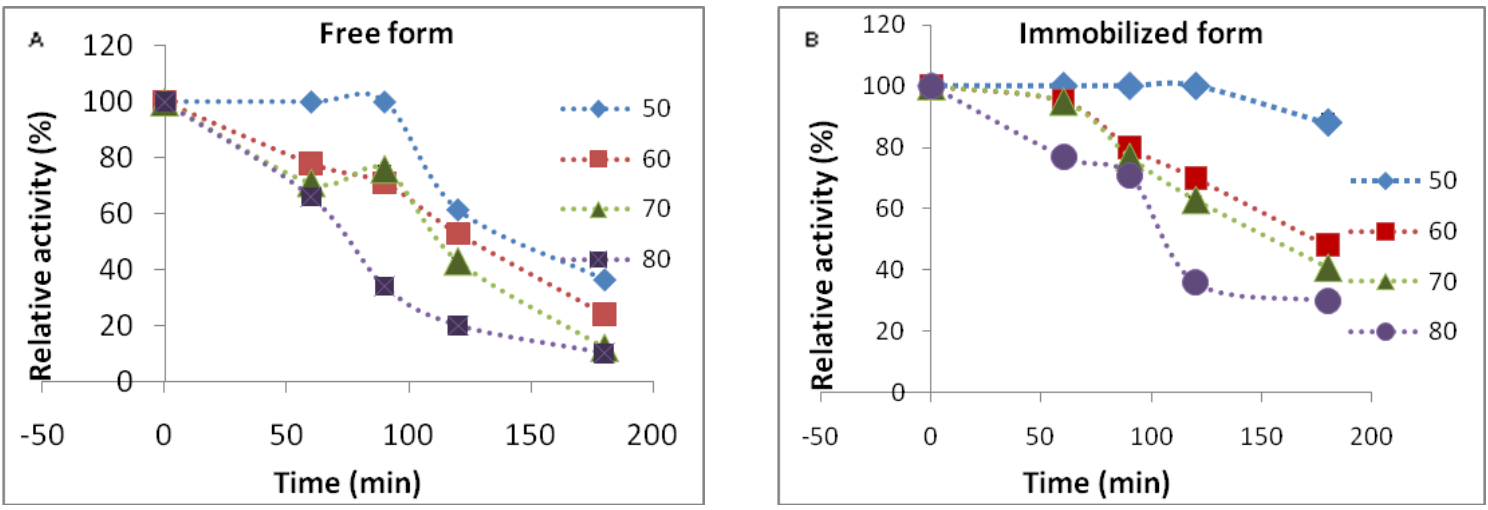

Fig. 4 a, b: Thermal stability studied on free and immobilized PPM.
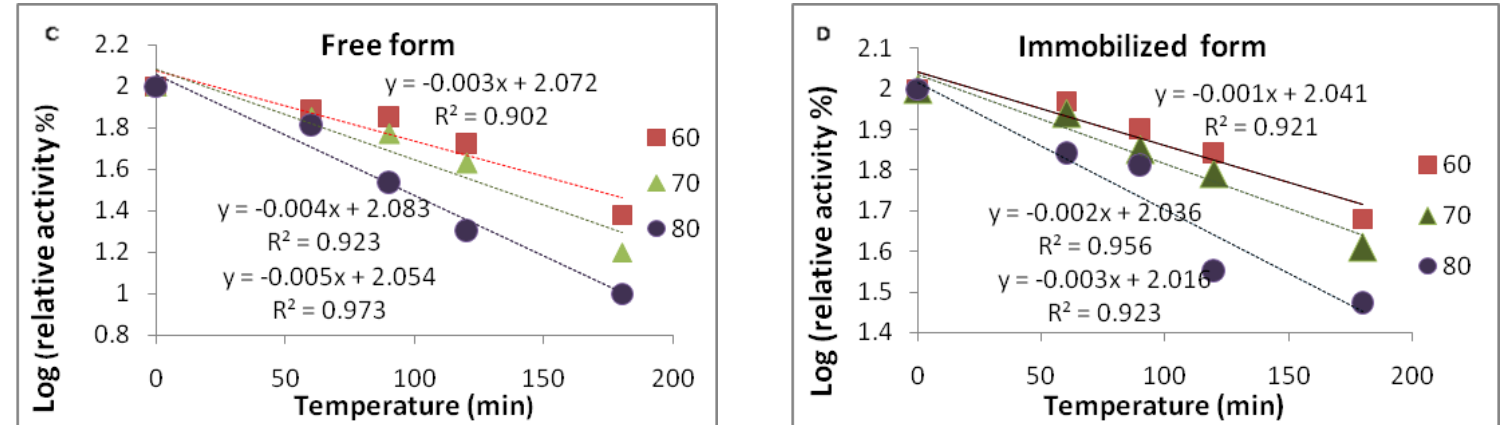

Fig. 4 c, d: First order of thermal deactivation of the free and immobilized form.
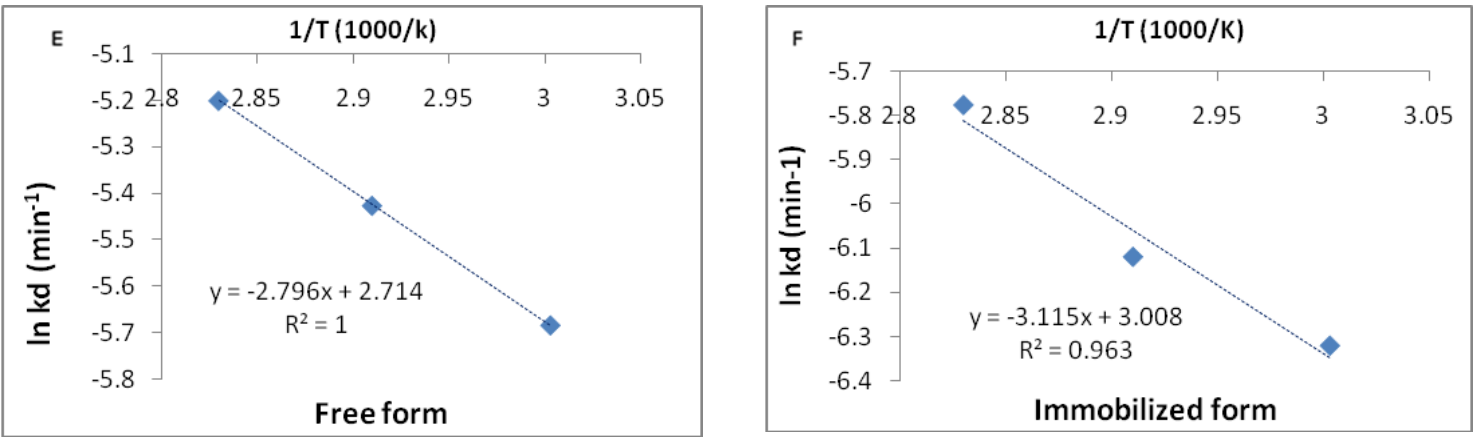

Fig. 4 e, f: Arrhenius plot to calculate activation energy for denaturation (Ed).

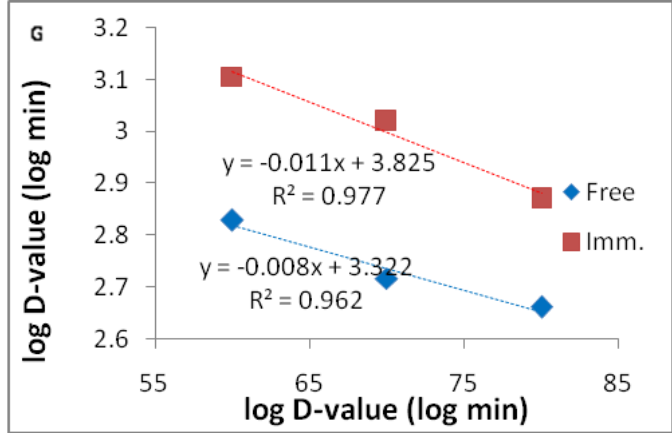

Fig. 4 g: Temperature dependence of the decimal reduction of free and immobilized PPM to calculate z- values. 


\section{Bioconversion of locust bean gum (LBG) and yeast mannan by free and mannanase form}

Bioconversion of $\mathrm{LBG}$ and yeast mannan prepared according to Edwards (1965) means hydrolysis of this galactomannanase into oligosaccharides and probably monosaccharides. The bioconversion process was achieved at optimum conditions for free and immobilized enzymes. The bioconversion percentage of LBG and yeast mannans by free PPM was found: $41 \%$. Also, Locust bean gum (LBG) and yeast mannan were subjected to a bioconversion process by using the immobilized mannanase preparation reported $23 \%$. The resulted partially hydrolyzed product was examined (by PC) (Figure 5) and found a major component appeared as brown spot with $\mathrm{R}_{\text {mann }}: 0.46$ for free and immobilized PPM.

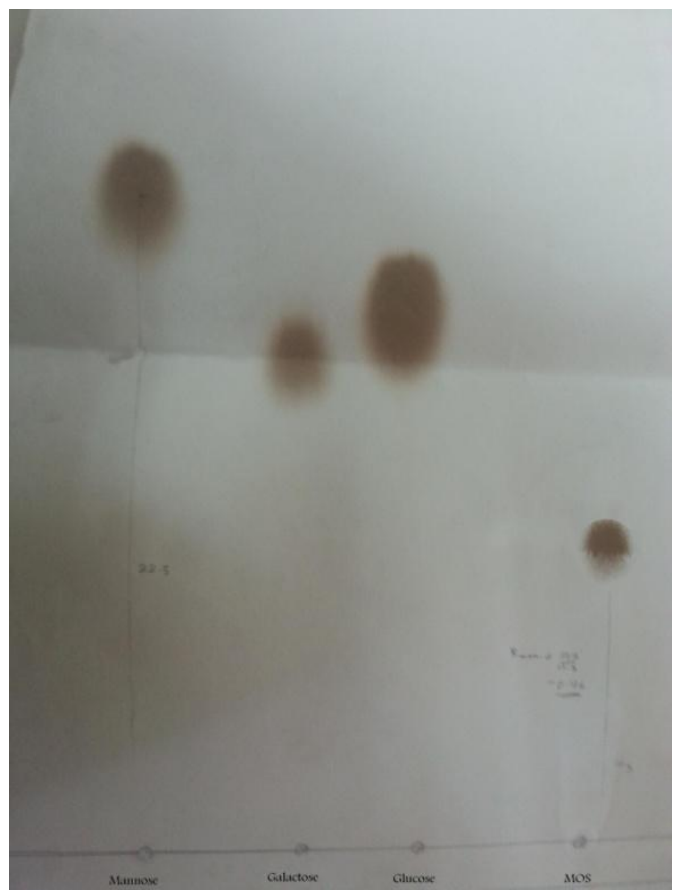

Fig. 5: Paper chromatography of MOS.

\section{Prebiotic activities of mannnooligosaccharides (MOS) comprising bio-converted samples of LBG and yeast mannanase}

Bioconverted samples (comprising MOS) of LBG and yeast mannan, were examined for their prebiotic activities towards the probiotics $L$. casei, L. helveticus and L. reuteri. The prebiotic indices were calculated on the proportion between the growth intensities of the probiotics (grown on MOS) and the growth intensity of E.coli (grown on MOS). The results (Figure 6) indicated that MOS originated from LBG characterized by their higher prebiotic activities toward $L$. helveticus and $L$. casei and slightly lower activity towards $L$. reuteri, comparing to the activities exhibited by MOS derived from yeast mannan. Noteworthy is that the highest prebiotic activity (prebiotic index 247) was recorded for MOS (of LBG) towards L. helveticus. On the other hand, the lowest prebiotic index (41.5) for L. helveticus grown on MOS obtained from bio-converted yeast mannan. This result was higher than the maltooligsaccharide effect obtained by Esawy et al. (2016) and galactooligosaccharide effect obtained by Hussein et al. (2009).

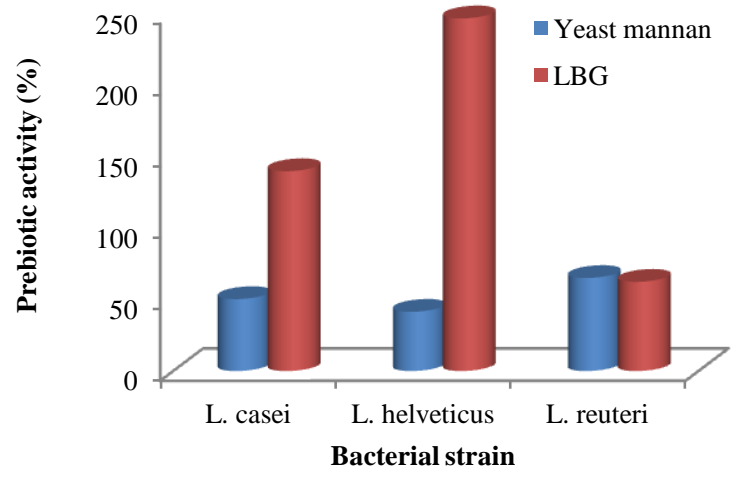

Fig. 6: Prebiotic activities of MOS

\section{Storage stability of the immobilized mannanase preparation}

The stability of the immobilized mannanase preparation was studied; it was known that storage stability is an important parameter recommend the enzyme in industrial use. Immobilized enzyme was stored for a long time at $\left(4^{\circ} \mathrm{C}\right)$ and periodically, the enzyme activity was measured during 60 days. The results clarified that the immobilized mannanase was stable for a long period at $4{ }^{\circ} \mathrm{C}$ retaining $90 \%$ of the activity after 60 days. The immobilization appeared good storage stability which could be back to the holding of the enzyme in a same position. Also, the immobilization acquired the enzyme molecule rigidity and decreases the enzyme molecule interaction which manages it to overcome the deactivation and autolysis by proteolytic enzymes (Vu and Le 2008).

Finally, it is worthy to add that the results of the present work may offer a promising base for further studies on microbial mannanases. Thus, hope is holding out that further investigation will include other local fungal isolates to produce mannanase with higher activities and longer stability times.

\section{CONCLUSION}

A local isolate of $P$. chrysogenum was found as a higher producer of mannanase. A crude product (CF) of this enzyme was attained by growing the aforementioned fungal isolates on a guarcontaining medium. Comparative studied was done between the free and immobilized PPM. The optimum temperature and $\mathrm{pH}$, in addition to the thermal stability studied reported the superiority of the immobilized form in stability and rigidity in compared to the free enzyme. Also, both the free and immobilized form had the ability to convert LBG and yeast mannan to valuable MOS. The prebiotic indices indicated that MOS originated from LBG characterized by their higher prebiotic activities towards $L$. helveticus and L. casei. Noteworthy is the highest prebiotic activity (prebiotic index 247) was recorded for MOS (of LBG) 
towards L. helveticus. All previous results recommended PPM to be used in different aspects such food supplementary.

\section{ACKNOWLEDGMENTS}

Financial support and sponsorship: The authors thank National Research Centre for supporting this work. The manuscript was funded by the project NO.10050305.

Conflict of interests: There are no conflicts of interest.

\section{REFERRENCES}

Ariandi, Yopi and Meryandini A. Enzymatic hydrolysis of copra meal by mannanase from Streptomyces sp.BF3.1 for the production of mannooligosaccharides. Hayati Journal of Bioscience, 2015; 22: 79-86.

Blibech M., Chaari F., Bhiri F., Dammak I., Ghorbel R.E. and Chaabouni S.E. Production of mannno-oligosaccharides from locust bean gum using immobilized Penicillium occitanis mannanase. Journal of Molecular Catalysis B: Enzymatic, 2011; 73:11-115.

Blibech M., Ghorbel R.E., Fakhfakh I., Natrima P., Piens K. and Bacha A. Purification and characterization of a low molecular weight of $\beta$-mannanase from Penicillium occitanis Pol6 M. Applied Biochemistry and Biotechnology, 2010; 160:1227-1240.

Chaabouni S.E., Belghuith H., Hsairi I., Mrad K. and Ellouz R. Optimization of cellulase production by Penicillium occitanis. Applied Biochemistry and Biotechnology, 1995; 43: 267-269.

Chandra M.R.S., Lee Y.S., Park I. H., Zhou Y, Kim K K and Choi Y.L.Isolation, purification and characterization of a thermostable $\beta$ mannanase from Paenibacillus sp. DZ3. J Korean Soc Appl Biol Chem, 2011; 54:325-331

Dan Z, Wenxiang P, Gang S, Hongzhi L, Xue L. and Jingping Ge. Optimization of mannanase production by Bacillus sp. HDYM-05 through factorial method and response surface methodology African Journal of Microbiology Research, 2012; 9 176-182.

Dhawan S. and Kaur J. Microbial mannanases: an overview of production and applications. Critical Reviews in Biotechnology, 2007; 27: 197-216.

Driss D., Driss Z., Chaari F. and Ellouz Chaabouni S. Immobilization of His-tagged recombinant xylanase from Penicillium occitanis on Nickel-chelate Eupergit $\mathrm{C}$ for increasing digestibility of poultry feed Bioengineered, 2014; 4: 274-279.

Edwards T.E. Yeast polysaccharides (cited in Methods in carbohydrate chemistry pay, 1965; (176) Vol. V editors Roy L. Whistlerand James N. Be Miller press New York and London.

Esawy M.A., Gamal A.A., Kamel Z., Ismail A.S. and AbdelFattah A.F. Evaluation of free and immobilized Aspergillus niger NRC1ami pectinase applicable in industrial processes. Carbohydrate polymers, 2013; 92:1463-9.

Esawy M A, Gamal A.A, Helal, M, Hassan M. E., Hassanein, N.M. and Hashem A.M. Enzymatic synthesis using immobilized Enterococcus faecalis Esawy dextransucrase and some applied studies International Journal of Biological Macromolecules, 2016;92:56-62

Gibson G.R., Probert H.M., Van Loo J., Rastall R.A. and Roberfroid M.B. Dietary modulation of the human colonic microbiota: updating the concept of prebiotics. Nutrition Research Reviews, 2004; 17: 259-275.
Hussein M.M., Ghaly M.F., Shalaby Al.G., Osman M.Y. and Helal M.M. Production and prebiotic activity of exopolysaccharides derived from some probiotics. Egyptian Pharmaceutical Journal, 2015; 14: $1-9$.

Hussein M.M., Ghaly M.F., Osman M. Y. and Shalaby Al.G. The perbiotic activities of galactooligosaccharides extracted from lupin seeds with beneficial bacteria, bulletin of the Faculty of science Zagazig University, 31, 75-92.

Jayme $\mathrm{G}$ and knolle $\mathrm{H}$ Paper chromatography of sugar mixtures upon glass-fiber paper. Angew. Chem., 1956; 68: 243-246.

Laemmli U. K.Cleavage of structural proteins during the assembly of the head of bacteriophage T4. Nature, 1970; 227: 680-685.

Lee Y.K. and Salminen S. Handbook of Probiotics and Prebiotics $\left(2^{\text {nd }}\right)$ ed, 2009. Hoboken, N. J.: John Wiley and Sons, Inc.

Lowry O.H., Reseebrough N.T., Farr A. L. and Randall R.J. Protein measurement with the folin- phenol reagent. Journal of Biological Chemistry ,1952;193: 265- 275.

Mc Cleary B.V. B-D-Mannanase. Methods in Enzymology, 1988; 160:596-610.

Mendoza N., Arai M., Kawaguchi T., Cubol F.S., Panerio E.G., Yoshida T., Joson L.M. Isolation of mannan-utilizing bacteria and the culture conditions for mannanase production. World $\mathrm{J}$ Microbiol Biotechnol, 1994; 10:51-54

Neish A.C. Analytical Methods of Bacterial Fermentation, Report no.46-8-3, Second revision, Natural Research Council Canada, 1952; pp. 34.

Quigley E.M.M. Prebiotics and Probiotics: modifying and mining the microbiota. Pharmacological Research, 2010; 61:213-218.

Somogi N. Notes on sugar determination. Journal of Biological Chemistry, 1952; 195: 19-23.

Tayefi-Nasrabadi H. and Asadpour R. Effect of heat treatment on buffalo (Bubalus bubalis) lactoperoxidase activity in raw milk. Journal of Biological Science, 2008; 8:1310-5.

Titapoka S., Keawsom ong S., Haltrich D. and Nitisinprasert S. Selection and characterization of mannanase-producing bacteria useful for the formation of prebiotic manno-oligosaccharides from copra meal. World Journal Microbiology and Biotechnology, 2008; 24: 1425-1433.

Tomotari M. and Indus J. Bifidobacteria and their role in human health, Journal of Industrial Microbiology, 1990; 6: 263-268.

$\mathrm{Vu}$ T.K.H. and Le, V.V.M. Biochemical studies on the immobilization of the enzyme invertase (EC. 3.2.1.26) in alginate gel and its kinetics. ASEAN Food J, 2008; 15, 73-78.

Whistler R.L. and BeMiller J.N. (eds.) Industerial Gums. Academic Press 1993 San Diego, CA.

Wilson, C. M. Quantitative Determination of Sugars on Paper Chromatograms. Anal. Chem., 1959; 31: 1199-1201.

Yopi, Awan, P., Ahmad T., Heri H. and Anondho W. Preparasi mannan dan mannanase kasar dari bungkil kelapa sawit. Journal of Teknol, 2006; 4: 312-319.

\section{How to cite this article:}

Shalaby AG, Esawy MA, Hussein MM. Comparative study between free and immobilized Penicillium chrysogenum mannanase: a local fungal isolate. J App Pharm Sci, 2017; 7 (06): 097-104. 